\title{
REPORT OF THE SCIENTIFIC FIELD SURVEY ON LAKE HOVSGOL AND ITS TRIBUTARIES
}

\author{
Prof. M.Sugiyama ${ }^{1}$, Prof. A.Dulmaa ${ }^{2}$, Prof. V.V.Drucker ${ }^{3}$ \\ ${ }^{1}$ Kyoto University, Japan \\ ${ }^{2}$ Institute of Biology, Mongolian Academy of Sciences, Mongolia,dulmaa@biology.mas.ac.mn \\ ${ }^{3}$ Limnological Institute, Irkutsk, Russian Academy of Sciences, Russia
}

Summary of the research until now and this year:

The present report gives an intermediate account of a collaborative research work at the Lake Hovsgol. The field survey took place from 9 August - 16 August, 2009 and covered sampling stations as follows, 15 stations at the Lake Hovsgol, 1 station on the Khar Us River, 1 station on the Egiin Gol River.

This international collaborative scientific research, "Material dynamics and ecological change in extra long water system, Hovsgol-Selenga-Baikal-Angara-Yenisey Waterched", supported from JSPS started in 2006. Nine Japanese scientists join this research. Their scientific major fields have a variety and are aquatic chemistry and analytical chemistry, aquatic ecology, limnological chemistry, bio-geochemistry, plant cell physiology, fishery physics and planktonic biology, microbiological ecology, organic geochemistry and phytoplankton ecology.

We have already surveyed Lake Baikal (2006 and 2007)8 Angara River (ListvyankaIrkutsk, 2006 and 2007\}, Lake Bratsk (2006), Yenisey River (Krasnoyarsk-Igarka, 2007) and Yenisey River (Didinca-Sopochunaya Karga, 2008) with Prof.Drucker. We have elucidated the water quality and distribution of biological community in their water areas. We have been also investigating the at now.

In this year, we have surveyed Lake Hovsgol and its tributaries. We collected surface water samples at 17 stations, vertical water samples at 2 stations, 6 water plants and planktonic organisms at 2 stations and 3 sediment samples at 2 stations. We measured transparency at all stations and elucidated vertical profiles of water temperature, electro conductivity, turbidity and chlorophyll fluorescense with multi water quality profiler. At almost all stations in pelagic area of Lake Hovsgol, transparency was beyond $15 \mathrm{~m}$. Chlorophyll-a concentrations in surface waters were below 1 micro-g/l. Vertical profile of chlorophyll fluorescence had a maximum value at around $50 \mathrm{~m}$ depth at almost stations. However, its maximum value was very low and was below 2 micro-g/l. These results suggest that Lake Hovsgol belongs to an oligotrophic or ultraoligotrophic lake. We will measure other chemical and biological indices of the collected samples and will discuss material dynamics and distribution of biological community in Lake Hovsgol and its tributaries in detail. 
Scientific planning in the next year: We are planning to perform the field survey on Egiin Gol and Selenga Rivers in Mongolia and Selenga Gol in Russian in the next year. Research program is the same as in this year.

Acknowledgements: We thank Prof.T.Janchiv (Director, Institute of Biology, Mongolian Academy of Sciences) for his kind cooperation and fruitful suggestion to our work. Scientific grant supporting this field survey was provided by the Japanese Society for Promotion of Science (JSPS) is hereby gratefully acknowledged. 